\title{
The Effects of Sucrose Substitution with Sorbitol on Physicochemical Properties and Sensory Evaluation of Seaweed Jelly Candy
}

\author{
Vanessa Natalie Jane Lekahena ${ }^{1, *}$, Mohammad Rifai Boboleha ${ }^{1}$ \\ ${ }^{I}$ DepartmeFishery Product Technology Study Program, Faculty of Agriculture, \\ Universitas Muhammadiyah Maluku Utara, Ternate, Indonesia \\ *Corresponding author.Email: enchalekahena@gmail.com
}

\begin{abstract}
Kappaphycus alvarezii seaweed is a type of algae that is widely cultivated in Indonesian waters because of its economic value and many uses, but post-harvest handling of this type of seaweed is only up to the drying process that produces dried seaweed, with low selling price. Diversification of Kappaphycus alvarezi seaweed into jelly candy is the one alternative to increase the economic value of seaweed. Jelly candy is transparent candy with clear texture and certain elasticity which made from mixture of water, sweeteners, fruit juice and gelling agent. This research aim is to determine the effect of sucrose substitution with sorbitol on physicochemical properties and sensory evaluation of seaweed jelly candy. Stages of research conducted include preparation of raw materials; making jelly candy; physicochemical characterization and sensory evaluation of jelly candy. The result of this research stated that substitution of sucrose with sorbitol gives significant effect on gel strength (361.36-1064.10 g.cm $\mathrm{cm}^{-2}$, moisture content (20.84-22.98\%), total sugar content (18.07-51.13\%), and acidity (4.64-4.74) and has not significant effect on ash content (0.30-0.43\%). Meanwhile the sensory evaluation has significant effect on the appearance, texture, color and taste, while not significant effect on the aroma.
\end{abstract}

Keywords: sucrose, sorbitol, seaweed, physiochemical properties

\section{INTRODUCTION}

Seaweed is a thallus-shapped plant that has no roots, stems and leaves [1]. Eucheuma cottonii or Kappaphycus alvarezii seaweed is a type of seaweed from the class of Rhodophyceae that widely utilized in food processing because it has essential nutrients like enzyme, nucleic acid, amino acid, mineral, vitamin, food fiber and carrageenan ranged between 54-73\%. Post-harvest handling of Kappaphycus alvarezii type of seaweed only up to the drying process that produced dried seaweed, with low selling price. Diversification of this processed seaweed into jelly candy or jelly gummy is done to increase the economic value of seaweed.

Candy confection is second in sales of all confectionery products and is the most favorite food in almost every circle of society. Candy is classified into hard candy, soft candy and gum [2]. Jelly candy is a product that made from water mixture, gelling agent, and sweetener with specific texture and characteristic [3], while according to SNI (2008), jelly candy is a soft candy made from the addition of hydrocolloid so it produces chewy textured products [2].

Jelly candy classified into semi-wet product that easily damaged, so it is necessary to add the preservatives to extend its shelflife [4]. Jelly candy is consists of a gelling agent mixed with a high ratio of sucrose and glucose syrup added with artificial flavoring and a coloring agent [5].

Gelling agent in the making of jelly candy in general is gelatin. Gelatin is a type of protein derived from collagen on animal's bones or leather [6]. Commercial gelatin generally still imported and expensive, also always related to halal issue, so other alternatives is needed to use materials that has similar characteristic with gelatin. One of the gel forming materials or hydrocolloid type is carrageenan which is polysaccharide obtained by the extraction from Kappaphycus alvarezii seaweed, however [7] stated that the characteristic of carrageenan gel is fragile and less elastic.

Sucrose or sugar is a grain of white crystals with a sweet taste (12-14\% of sucrose) extraction results of Saccharum officinarum plant that has been purified and stretched out [8]. Sucrose is a disaccharide compounds that composed from two monosaccharide that connected by the bond of glycosides from one carbon to one other unit of $\mathrm{OH}$. Sucrose has a sweet taste and easily soluble in water, so it is used as sweetener and preservative, beside that, sucrose is easy to obtain and the price is cheap. However, some of the research results shown that sucrose can cause dental caries, because during inside mouth cavity, the synthesis of 
sucrose is faster than any other sugar so it quickly transformed by microorganisms to become acid [9].

As a result now, the use of sucrose as sweetener starting to be reduced and replaced by other sweetener materials. Sucrose substitute materials must meet the requirements that must have a sweet taste, non-toxic, calories and inexpensive, and also cannot be fermented by dental plaque bacteria, in addition, it also should be done industrially. Of all these requirements, it substitutes a good sugar is derived from the group of sugar alcohols. Sorbitol is a sugar substitute material from the group of sugar alcohols most widely used, especially in Indonesia. Sorbitol is a sugar alcohol with a sweet taste that slowly metabolized by human body because of the sucrose reduction as a result of converting the aldehyde group to hydroxyl. Sorbitol is made from corn syrup, apple, pear, peach, and plum [10]. The sweet taste of sorbitol is $\pm 60 \%$ from the sweet taste of sucrose [9].

This research aims to determine the effect of sucrose substitution with sorbitol on the physicochemical properties and sensory evaluations of seaweed jelly candy.

\section{METHODS}

The tools used in the making of jelly candy are plastic container, scissor, knife, blender, cooking pan, spatula stirrer, stove, mold, drying oven, thermometer, timer and writing tools, while for the physical and chemical test such as, oven, furnace oven, $\mathrm{pH}$ meter, TA-XT plus texture analyzer and glassware and titration for the total sugar content test. Dried seaweed Kappaphycus alvarezii obtained from Kolorai District Morotai Island, and several additional ingredient such as sucrose, sorbitol, dye, essence, natrium benzoate, tapioca flour and fine granulated sugar. Other materials for the chemical test like $\mathrm{HCl}, \mathrm{NaOH}$, aquades, Luff Schrool solution and starch.

Preparation samples, seaweed is washed and soaked with $1 \%$ lime betel 10 times of dry seaweed's weight for 8 hours, drained and cut in size of 2-3 cm. $200 \mathrm{~g}$ of seaweed added with $1000 \mathrm{ml}$ water mixture until it becomes seaweed porridge. The seaweed porridge then cooked on $100{ }^{\circ} \mathrm{C}$ temperature, for 15 minutes, after which the sweetener added, according to the treatment which is: $\mathrm{A}_{1}$ ( $100 \%$ sucrose), $A_{2}$ (75\% sucrose $+25 \%$ sorbitol), $A_{3}(50 \%$ sucrose $+50 \%$ sorbitol $)$ and $\mathrm{A}_{4}(25 \%$ sucrose $+75 \%$ sorbitol) then added $1 \mathrm{ml}$ dye (food grade), $1 \mathrm{ml}$ essence, and $1 \mathrm{~g}$ sodium benzoate, stirred and cooked for 20 minutes on $100{ }^{\circ} \mathrm{C}$ temperature until cooked evenly, set aside, cooled, molded and settled at room temperatures for 1 hour until solid and chewy then cut and dried using the oven on $50{ }^{\circ} \mathrm{C}$ temperatures for 48 hours, and given the coating ingredients in the form of sugar and tapioca flour that roasted. Analysis procedure of sample obtained using moisture content [11], ash content [12], $\mathrm{pH}$ value [13], total sugar content [14] and texture analyzer [15], as well as hedonic test [16].

Statistical of research is using the single factor completely randomized design with 3 replication on each treatment.
The data of physicochemical analysis and sensory evaluation were evaluated using SPSS 22 program for ANOVA single factor if significant with further Least Significance Different (LSD).

\section{RESULTS AND DISCUSSION}

The results of physicochemical test of seaweed jelly candy can be seen on the following Table 1 below:

Table 1. Physicochemical properties of seaweed jelly candy

\begin{tabular}{|l|r|r|r|r|}
\hline $\begin{array}{l}\text { Physicochemic } \\
\text { al properties }\end{array}$ & $\mathbf{A}_{\mathbf{1}}$ & \multicolumn{1}{|c|}{$\mathbf{A}_{\mathbf{2}}$} & \multicolumn{1}{c|}{$\mathbf{A}_{\mathbf{3}}$} & \multicolumn{1}{c|}{$\mathbf{A}_{\mathbf{4}}$} \\
\hline $\begin{array}{l}\text { Gel strength } \\
\text { (g.cm }^{-2} \text { ) }\end{array}$ & $361.36^{\mathrm{a}}$ & $480.12^{\mathrm{a}}$ & $826.15^{\mathrm{b}}$ & $1064.10^{\mathrm{c}}$ \\
\hline Moisture (\%) & $22.98^{\mathrm{b}}$ & $22.39^{\mathrm{b}}$ & $20.99^{\mathrm{a}}$ & $20.84^{\mathrm{a}}$ \\
\hline Ash (\%) & $0.30^{\mathrm{a}}$ & $0.30^{\mathrm{a}}$ & $0.36^{\mathrm{a}}$ & $0.43^{\mathrm{a}}$ \\
\hline Total sugar (\%) & $51.13^{\mathrm{d}}$ & $38.03^{\mathrm{c}}$ & $34.10^{\mathrm{b}}$ & $18.07^{\mathrm{a}}$ \\
\hline Acidity (pH) & $4.63^{\mathrm{a}}$ & $4.64^{\mathrm{a}}$ & $4.74^{\mathrm{b}}$ & $4.68^{\mathrm{a}}$ \\
\hline
\end{tabular}

Remarks: The number followed by the same letter on the same line is not significantly different at $\alpha 0.05$

$\mathrm{A}_{1}\left(100 \%\right.$ sucrose), $\mathrm{A}_{2}$ (75\% sucrose $+25 \%$ sorbitol), $\mathrm{A}_{3}(50 \%$ sucrose $+50 \%$ sorbitol $), A_{4}(25 \%$ sucrose $+75 \%$ sorbitol $)$

\section{Gel Strength}

Gel strength is a property of object or food product in terms of endurance to break due to non-deformation compressive force ${ }^{[17]}$, while hardness is the amount of compressive force to break the food product. The test result of gel strength of jelly candy (Table 1), ranged between $361.36-1064.10$ g.cm $\mathrm{cm}^{-2}$. The highest value is on the jelly candy with $25 \%$ sucrose and $75 \%$ sorbitol $\left(\mathrm{A}_{4}\right)$ and the lowest value is on the jelly candy with $100 \%$ sucrose without sorbitol $\left(\mathrm{A}_{1}\right)$. Analysis of variance results shown that substitution of sucrose with sorbitol gives significant effect compared to the controls or other treatment on the gel strength. The gel strength of jelly candy in this study was less than jelly candy which formulated using k-carrageenan and konjac which ranged from 447-2340 g.cm ${ }^{-2}$ [3].

The higher sorbitol concentration used on the making of jelly candy produces candy with chewy texture and high gel strength, while the jelly candy with $100 \%\left(\mathrm{~A}_{1}\right)$ and $75 \%\left(\mathrm{~A}_{2}\right)$ sucrose concentration have a dry, rigid and nonchewy texture, so it is easily cracked and broken when given the pressure and has a low gel strength. When sucrose is substituted with sorbitol on $50 \%\left(\mathrm{~A}_{3}\right)$ and $75 \%$ $\left(\mathrm{A}_{4}\right)$ concentration produces jelly candy with chewy texture and a fine gel strength, so it needed a bigger pressure or load to crack or brake the produced jelly product.

The gel forming characteristic of jelly candy, beside the effect of additional sorbitol sweetener materials, also formed because of the carrageenan content of the seaweed which is used as basic materials. The use of sucrose with high concentration can lead to syneresis so the surface of produced jelly candy is drier, easily broke and not chewy. 


\section{Moisture Content}

Moisture content of food product is an important factor on quality, preservation and resistance to damage. Measurement of moisture content in food product is needed to calculate other element composition evenly or in dry weight, or known as total solids [18]. Moisture content in food products also determine the acceptability, freshness and materials durability, because it can effected the visibility, texture and food taste [19].

Moisture content of seaweed jelly candy ranged between $20.84-22.98 \%$ (Table 1), with the highest moisture content on jelly candy with $100 \%$ sucrose without sorbitol $\left(\mathrm{A}_{1}\right)$ and lowest on jelly candy with $25 \%$ sucrose and $75 \%$ sorbitol $\left(\mathrm{A}_{4}\right)$. Analysis of variance results shown that the substitution of sucrose with sorbitol gives significant effects on the moisture content of jelly candy product. The higher the concentration of sorbitol used as a substitute for sucrose, the lower moisture content produced.

\section{Total Ash}

Total ash is an organic residue from combustion of organic matter. Ash content is mineral content of material, in the form of organic salt such as malate, oxalate, acetate, pectate and inorganic salt such as phosphate, carbonate, chloride, sulfate and nitrate [20]. Ash content of seaweed jelly candy (Table 1) ranged between $0.30-0.43 \%$ with the highest value on jelly candy with $25 \%$ sucrose and $75 \%$ sorbitol $\left(\mathrm{A}_{4}\right)$ and lowest on jelly candy with $100 \%$ sucrose without sorbitol $\left(A_{1}\right)$. Analysis of variance results shown that substitution of sucrose with sorbitol has no significant effects on the ash content of jelly candy which means the treatments of substitution of sucrose and sorbitol that shown no significant effects compared to the controls and other treatments on the ash content of jelly candy.

\section{Acidity $(p H)$}

Acidity $(\mathrm{pH})$ is an important parameter on determining the quality of a food product which is the freshness of product. Acidity $(\mathrm{pH})$ of seaweed jelly candy (Table 1) ranged between $4.63-4.74 \%$, with the highest value on jelly candy with $50 \%$ sucrose and $50 \%$ sorbitol $\left(\mathrm{A}_{3}\right)$ and the lowest on jelly candy with $100 \%$ sucrose without sorbitol $\left(\mathrm{A}_{1}\right)$. Analysis of variance results shown that the substitution of sucrose with sorbitol has significant effects on acidity $(\mathrm{pH})$ of jelly candy which means there is minimum of one significant treatment compared to the controls.

\section{Total Sugar Content}

Total sugar content is an important parameter on determining the characteristic of candy quality. Total sugar content of seaweed jelly candy (Table 1) ranged between $18.07-51.13 \%$, with the highest value on jelly candy with $100 \%$ sucrose without sorbitol $\left(\mathrm{A}_{1}\right)$ and the lowest on jelly candy with $25 \%$ sucrose and $75 \%$ sorbitol $\left(\mathrm{A}_{4}\right)$. Analysis of variance results shown that substitution of sucrose with sorbitol has significant effects on total sugar content of jelly candy. The substitution of sucrose with sorbitol effecting the total sugar content of seaweed jelly candy product, the higher of sucrose concentration, the higher the total sugar content, while the higher the sorbitol concentration, the lower the total sugar content.

\section{Sensory Evalution}

Sensory evaluation is a characterization process of food using the human's five senses which is sight, smell, taste, sound and touch [21]. Sensory evaluation is a scientific method of food quality test based on sensory characteristic using the five senses. Sensory evaluation on this research is to measure the acceptance level of consumer of the jelly candy product using the hedonic test. Consumers tend to choose food with an interesting appearance caused appearance is the first characteristics perceived by the human senses and play an important role in the identification and final selection of food [22]. The appearance score of jelly candy ranged between 6.61-7.33 which means rather like to like, with the highest score on treatment $\mathrm{A}_{4}$ (7.33), and the lowest on treatment $\mathrm{A}_{1}$ (6.61). Analysis of variance results shown that substitution of sucrose with sorbitol has significant effects on the appearance of jelly candy.

Table 2. Sensory evaluation of seaweed jelly candy

\begin{tabular}{|l|l|l|l|l|}
\hline $\begin{array}{c}\text { Sensory } \\
\text { Attribute }\end{array}$ & $\mathbf{A}_{\mathbf{1}}$ & $\mathbf{A}_{\mathbf{2}}$ & $\mathbf{A}_{\mathbf{3}}$ & $\mathbf{A}_{\mathbf{4}}$ \\
\hline Appearance & $6.61^{\mathrm{a}}$ & $6.78^{\mathrm{a}}$ & $7.15^{\mathrm{b}}$ & $7.33^{\mathrm{b}}$ \\
\hline Texture & $7.42^{\mathrm{c}}$ & $7.20^{\mathrm{c}}$ & $6.84^{\mathrm{a}}$ & $6.46^{\mathrm{b}}$ \\
\hline Color & $6.86^{\mathrm{a}}$ & $7.11^{\mathrm{b}}$ & $7.49^{\mathrm{c}}$ & $7.47^{\mathrm{c}}$ \\
\hline Aroma & $6.82^{\mathrm{a}}$ & $6.93^{\mathrm{ab}}$ & $7.12^{\mathrm{ab}}$ & $7.30^{\mathrm{b}}$ \\
\hline Taste & $6.83^{\mathrm{a}}$ & $7.11^{\mathrm{b}}$ & $7.77^{\mathrm{c}}$ & $7.54^{\mathrm{c}}$ \\
\hline
\end{tabular}

Remarks: The number followed by the same letter on the same line is not significantly different at $\alpha 0.05$

$A_{1} \quad(100 \%$ sucrose $), A_{2}(75 \%$ sucrose $+25 \%$ sorbitol $), A_{3} \quad(50 \%$ sucrose $+50 \%$ sorbitol $), \mathrm{A}_{4}(25 \%$ sucrose $+75 \%$ sorbitol $)$

Texture is included as an important physical properties of food, because it is related to the sensation while chewing it. The processed to determine the food texture is by giving a pressure to the sample by using the finger pressure [21]. The texture value of jelly candy ranged between 6.46-7.42 (Table 2) which is rather like to like, with the highest value on treatment $\mathrm{A}_{1}(7.42)$ and the lowest on treatment $\mathrm{A}_{4}$ (6.46). Analysis of variance results shown that substitution of sucrose with sorbitol has significant effects on the texture of jelly candy. Formulating jelly candies with carrageenan can eliminate sticking to the teeth and also offer a range of desirable textures from soft, easy to chew to firmer, short textured candies. Jelly candy made with carrageenan provide clean flavor release, decreased set up time, and heat stability upon storage.

Color is also an important attribute on determining quality and consumer acceptance on food. Food with a good texture, but if it has a less interesting color and unpleasant to look at will not be eaten. Color value of jelly candy ranged between 6.86-7.49 (Table 2), which is rather like to like, with the highest value on treatment $A_{3}$ (7.49) and the 
lowest on treatment $A_{1}$ (6.86). Analysis of variance results shown that substitution of sucrose with sorbitol has a very real effects on the color of jelly candy. The substitution of sucrose and sorbitol on 50 and $75 \%$ concentration, produces jelly candy with a brighter and preferred color. Jelly candy with high sucrose concentration change of color and dull when dried in the sun so less favored by consumers.

The aroma testing generally uses the sense of smell, and also has an important role in determining the level of assessment and quality of food, because it is a significant factor, beside shape and color. Aroma value of jelly candy ranged between 6.82-7.30 (Table 2), which rather like to like, with the highest value on treatment $\mathrm{A}_{4}$ and the lowest on treatment $\mathrm{A}_{0}$. Analysis of variance results shown that substitution of sucrose with sorbitol has not significant effects on jelly candy aroma or substitution of sucrose with sorbitol is not effecting the acceptance of consumers on the aroma attribute of jelly candy.

Taste is an important factor in sensory evaluation because it affects ones acceptance on food and the test is by using tongue senses. Delicious food can attract the attention because consumers generally tend to like the food of its taste. Taste of food ingredients actually consists of 3 components which is: aroma, taste, and mouth stimulation [23]. Taste value of jelly candy ranged between 6.83-7.77 (Table 2) which rather like to like, with the highest value on treatment $\mathrm{A}_{3}$ (7.77) and the lowest on treatment $\mathrm{A}_{1}$ (6.83). Analysis of variance results shown that substitution of sucrose with sorbitol has significant effects on the taste of jelly candy. This shown that substitution of sucrose with sorbitol affects the consumer acceptance level on the taste of seaweed jelly candy. The bigger the sorbitol concentration used, the higher consumer acceptance level on the taste of jelly candy.

\section{CONCLUSION}

The results of this research can be concluded that substitution of sucrose with sorbitol gives significant effect on gel strength, moisture content and total sugar content, and acidity $(\mathrm{pH})$ and has no significant effect on ash content. While the sensory evaluation has significant effect on appearance, texture, color and taste, but not significant effect on aroma. This research shown that substitution of sucrose and sorbitol in the making of jelly candy affects the physicochemical characteristic and sensory evaluation of jelly candy.

\section{REFERENCES}

[1] Aslan LM. 2005. Budidaya Rumput Laut. Cetakan 6. Penerbit Kanisius Yogyakarta.

[2] SNI [Standar Nasional Indonesia]. 2008. SNI. 3547.2.2008. Kembang Gula Bagian 2: Lunak. ICS-67.180.20. Badan Standarisasi Nasional Indonesia. Jakarta.
[3] Utomo BSB, Darmawan M, Rahman AH, Ardi DT. 2014. Physicochemical properties and sensory evaluation of jelly candy made from different ratio of carrageenan and konjac. Squalen Bulletin of Marine \& Fisheries Postharvest \& Biotechnology 9(1): 25-34.

[4] Minarni. 1996. Mempelajari Pembuatan dan Penyimpanan Perman Jelly Gelatin dari buah kweni. [Skripsi] Fateta. IPB. Bogor.

[5] Marfil P, Anhe A, Telis V. 2012. Texture and microstructure of gelatin/corn starch based gummy confections. Food Biophysics 7: 236243.

[6] Tau T, Gunasekaran S. 2016. Thermorheological evaluation of gelation of gelatin with sugar substitues. LWT-Food Science and Technology 69: 570-578.

[7] Subaryono, Bagus S. 2006. Penggunaan Campuran Karaginan dan Konjak dalam Pembuatan Permen Jelly. Jurnal Pascapanen dan Bioteknologi Kelautan dan Perikanan Vol. 1 No. 1. Juni 2006.

[8] WP [Wikimedia Project]. 2010. Bahan Pemanis. Wikipedia: Ensiklopedia bebas. Media Wiki.id. Wikipedia. Org/wiki/bahanpemanis.

[9] [9] Harris NO, Christen AG. 1995. Primary preventive dentistry. 4th ed. Connectitut. Appleton and Lange. p. 342-8.

[10] Teo G, Suzuki Y, Uratsu SL, Lampinen B, Ormonde N, Hu WK, Dejong TM, Dandekar AM. 2006. Silencing leaf sorbitol synthesis alters long-distance partitioning and apple fruit quality. Proceedings of the National Academy of Sciences of the United States of America. 103 (49): $\quad$ 18842-18847. doi: 10.1073 /pnas.0605873103. PMC 1693749PMID1713274

[11] SNI [Standar Nasional Indonesia]. 2006. SNI: 01-2354.2-2006. Cara Uji Kimia Bagian 2: Penentuan Kadar Air Pada Produk Perikanan. ICS. 67.120.30 Badan Standar Nasional Indonesia. Jakarta

[12] SNI [Standar Nasional Indonesia]. 2006. SNI: 01-2354.1-2006. Cara Uji Kimia Bagian 1: Penentuan Kadar Abu Pada Produk Perikanan. ICS. 67.120.30 Badan Standar Nasional Indonesia. Jakarta

[13] Suwetja IK. 2007. Biokimia Hasil Perikanan Jilid III. Rigormortis, TMAO, dan ATP. Fakultas Perikanan dan Ilmu Kelautan. Universitas Sam Ratulangi Manado.

[14] Sudarmadji S, Bambang H, Suhardi. 1997. Prosedur Analisa Untuk Bahan Makanan dan Pertanian. Edisi ketiga. Penerbit Liberty. Yogyakarta.

[15] Tuazon M. 1996. The use of carragenan and cellulose gel in gummy candy. The Manufacturing Confections 76(11):62-66. 
[16] SNI [Standar Nasional Indonesia]. 2006. SNI: 012346-2006. Petunjuk Pengujian Organoleptik dan Sensorik. Badan Standar Nasional Indonesia. Jakarta

[17] Soekarto ST, Hubeis M. 2000. Metodologi Penelitian Organoleptik. Program Studi Ilmu Pangan. Institut Pertanian Bogor.

[18] Nielsen SS. 2009. Determination of Moisture Content. Food Science Texts Series book series (FSTS). Food Analysis Laboratory Manual pp 17-27.

[19] Winarno FG. 1997. Kimia Pangan dan Gizi. PT. Gramedia Pustaka Utama. Jakarta.

[20] Fennema OR. 1996. Food Chemistry. Third Edition.University of Wiscorsin Madison. New York

[21] Lawless HT, Heymann H. 1998. Sensory Evaluation of Food Principles and Practices. Chapman \& Hall. New York.

[22] Sharif MK, Butt MS, Sharif HR, Nasir M. Chapter 14: Sensory Evaluation and Consumer Acceptability

[23] Rampengan V, Pontoh J, Sembel DT. 1985. Dasar-dasar Pengawasan Mutu Pangan. Badan Kerjasama Perguruan Tinggi Negeri Indonesia Bagian Timur, Ujung Pandang. 